\title{
Perancangan Alat Penanggulangan Kebakaran Berbasis Mikrokontroler Arduino Uno R3
}

\author{
Bintang Ramadhan ${ }^{1}$, Muhammad Amin ${ }^{2}$, Hidayatullah ${ }^{3}$ \\ ${ }^{1,2,3}$ STMIK Royal Kisaran, Indonesia \\ stmikroyal13@gmail.com
}

\begin{tabular}{l}
\hline open \\
Histori Artikel: \\
Diajukan: 20 June 2021 \\
Disetujui: 25 June 2021 \\
Dipublikasi: 30 June 2021 \\
\hline Kata Kunci: \\
Mikrokontroller; Flame \\
Sensor; Actuator; \\
\hline Digital Transformation \\
Technology (Digitech) is an \\
Creative Commons License This \\
work is licensed under a \\
Creative Commons Attribution- \\
NonCommercial 4.0 \\
International (CC BY-NC 4.0). \\
\hline
\end{tabular}

\begin{abstract}
Abstrak
Maraknya korban jiwa pada kebakaran disebabkan karena kurangnya pengamanan dan lambatnya sistem pengamanan yang terdapat pada suatu peristiwa kebakaran, sebuah kelalaian dan labatnya proses pengamanan menjadi suatu hal yang dapat menimbulkan korban jiwa, akan tetapi dengan kita mengembangkan dan memanfaatkan teknolgi kita bisa membuat sebuah inovasi baru untuk mengantisipasi berbagai bencana yang terjadi. Metode yang digunakan dalam pembuatan alat ini dengan cara metode eksperimen. Alat ini bekerja mendeteksi cahaya api menggunakan Flame Sensor dan mendeteksi asap menggunakan Sensor MQ2 lalu keluaran sensor berupa data yang diolah oleh arduino dengan menggunakan pemograman yang sudah diprogram dengan actuator berbentuk buzzer, ISD 1820, servo dan relay.
\end{abstract}

\section{PENDAHULUAN}

Kebakaran merupakan salah satu musibah yang paling sering terjadi baik di beberapa kota besar maupun di pedesaan. Hampir setiap hari kita membaca di koran atau melihat siaran di televisi tentang musibah kebakaran yang terjadi baik dalam rumah penduduk, gedung perkantoran, hotel, pertokoan atau pasar. Bencana kebakaran sangat berbahaya karena dapat memakan korban jiwa. Selain itu kebakaran yang terjadi di kawasan penghunian ataupun perdagangan akan menimbulkan kerugian material dan ekonomi yang besar. kondisi dan beberapa syarat pencetusnya terpenuhi, utamanya pada saat pra kejadian.

Kebakaran disebabkan oleh berbagai faktor yang biasa disebabkan oleh manusia secara langsung ataupun tidak langsung atau disebabkan oleh alam. Api yang dapat memicu kebakaran juga memiliki sumber penyalaan, tidak hanya berasal dari sumber api secara langsung tetapi sumber api dapat disebabkan dari berbagai kegiatan manusia yang secatra tidak langsung dapat menimbulkan api. Kebakaran yang disebabkan faktor alam yaitu petir, gempa bumi, letusan gunung berapi, dan kekeringan, sedangkan kebakaran yang disebabkan oleh faktor manusia biasanya disebabkan akibat kelalaian diantaranya adalah pemasangan instalasi listrik tidak sempurna, penggunaan peralatan memasak, perilaku manusia seperti menyalakan api untuk penerangan ditempat penyimpanan bahan bakar (bensin) yang mudah terbakar, menempatkan obat nyamuk, lilin, lampu teplok yang sedang menyala ditempat mudah terbakar, serta penggunaan peralatan listrik yang berlebihan melampaui beban yang aman.

\section{STUDI LITERATUR}

Mikrokontroler merupakan suatu IC yang di dalamnya berisi CPU, ROM, RAM, dan I/O. Dengan adanya CPU tersebut maka mikrokontroler dapat melakukan proses berfikir berdasarkan program yang telah diberikan kepadanya. Mikrokontroler dapat disebut pula sebagai komputer yang berukuran kecil yang berdaya rendah sehingga sebuah baterai dapat memberikan daya (Putra et al., 2017).

Perancangan Sistem Pendeteksi Asap Pada Ruangan Perpustakaan Menggunakan Sensor MQ-2 Dan Tampilan LCD Dengan Mikrokontroler ATMega32.Diteliti oleh : Ruri Hartika Zain, Sahari, Elmi Rahmawati pada tahun 2016. Hasil Penelitian : Sistem pendeteksi asap ini bekerja secara otomatis tanpa adanya kendali dari luar sistem, dan dikendalikan melalui mikrokontroler untuk menampilkan kadar jumlah asap dalam satuan PPM pada $L C D$ sebagai output dari inputan sensor MQ-2 (Iskandar Alam et al., 2019).

Arduino IDE merupakan singkatan dari Arduino Integrated Development Environment, yakni software terintegrasi yang digunakan untuk membuat program dan memasukkannya kedalam board Arduino. Arduino IDE menggunakan bahasa pemrograman sendiri yang biasa disebut sebagai Arduino Sketch (Bahari \& Sugiharto, 2019). 


\section{METODE}

Untuk membantu dalam penyusunan penelitian ini, maka perlu adanya susunan kerangka kerja (frame work) yang jelas tahapan-tahapannya. Kerangka kerja ini merupakan langkah-langkah yang dilakukan dalam penyelesaian masalah yang akan dibahas. Adapun kerangka kerja penelitian yang akan digunakan adalah sebagai berikut:

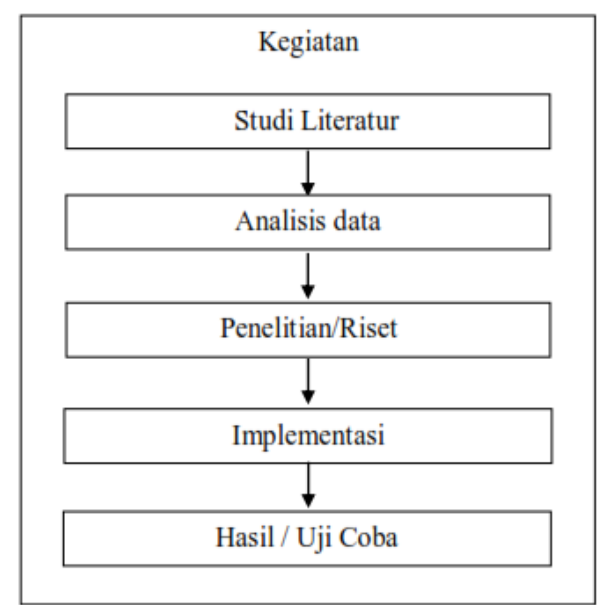

\section{Gambar 1. Kerangka Kerja Penelitian}

\section{Komponen Alat Penanggulangan Kebakaran}

Komponen Input

Komponen input adalah alat yang berfungsi untuk memasukkan data atau perintah yang nantinya kakan di proses oleh mikrokontroller arduino uno. Dalam Perancangan alat ini saya menggunakan dua input yaitu:

1. Flame sensor

Komponen input pada alat tersebut adalah sensor api (flame sensor) digunakan untuk mendeteksi api yang ada didepannya dan. Sensor akan mengirimkan sinyal ke Arduino jika sensor mendeteksi adanya api.

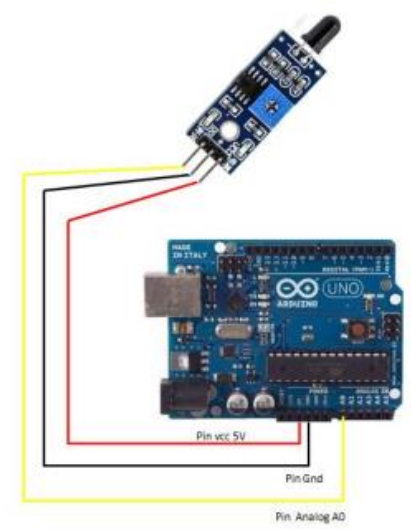

Gambar 2. Rangakaian Komponen Flame Sensor

\section{Sensor MQ2}

Komponen input pada alat tersebut adalah sensor asap (MQ2) digunakan untuk mendeteksi asap yang ada pada ruangan dan Sensor akan mengirimkan sinyal ke Arduino jika sensor mendeteksi adanya asap. 


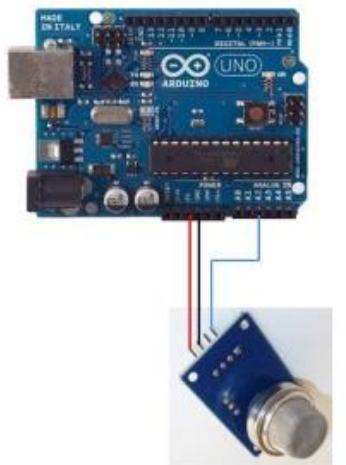

Gambar 3. Rangkaian Komponen Sensor MQ2

\section{Komponen Output}

Komponen output adalah perangkat yang mengeluarkan hasil dari proses mikrokontroller arduino uno. Pada bagian output komponen yang digunakan yaitu buzzer, servo dan relay yang berfungsi untuk memberikan bunyi beep, membuka pintu darurat dan menggaktifkan pompa air ketika flame sensor mendeteksi api.

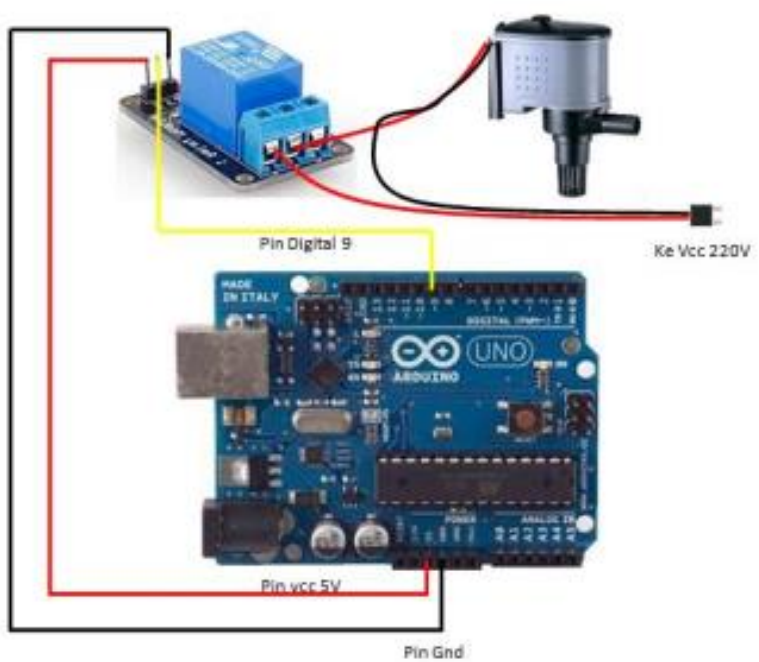

\section{Pengujian Komponen}

\section{Gambar 4. Rangkaian Komponen Relay}

Setelah tahap perancangan dan perakitan komponen telah selesai, maka langkah selanjutnya yang harus dilakukan adalah melakukan pengujian dari komponen. Tujuan pengujian adalah untuk mengetahui apakah komponen yang terhubung dalam alat ini dapat berjalan sesuai dengan yang diharapkan.

Pengujian Rangkaian Komponen Flame Sensor

Flame sensor sangat sensitif terhadap infrared yang panjang gelombang cahaya nya $760-1100 \mathrm{~nm}$ (nano meter). Analog output (A0): Real-time sinyal tegangan output pada tahan panas. Dengan pin Analog Output ini kita bisa memperkirakan letak api. Dengan memasang sensor secara parallel, kita bisa memperkirakan kira - kira posisi api dimana, meskipun tidak terlalu akurat. 
Tabel 1. Hasil Pengujian Flame Sensor

\begin{tabular}{|c|c|c|c|}
\hline No. & Jarak (cm) & Kondisi & Indikator \\
\hline 1 & 10 & Flame Detected & On \\
\hline 2 & 30 & Flame Detected & On \\
\hline 3 & 60 & Flame Detected & On \\
\hline 4 & 90 & Flame Detected & On \\
\hline 5 & 100 & No Detected & Off \\
\hline
\end{tabular}

Berdasarkan hasil pengujian diatas dapat dilihat perubahan nilai pengukuran menggunakan sensor ultrasonik terdapat perubahan nilai pada jarak $100 \mathrm{~cm}$. Nilai di dapat dari hasil pengukuran Flame Sensor adalah $90 \mathrm{~cm}$.

Pengujian Rangkaian Komponen Sensor $M Q 2$

Sensor $M Q 2$ merupakan sensor gas monoksida yang berfungsi untuk mengetahui keberadaan gas karbon monoksida, dimana sensor ini yang di pakai untuk memantau kebe radaan asap dalam peneletian ini.

Tabel 2. Hasil Pengujian Sensor MQ2

\begin{tabular}{|l|l|}
\hline \multicolumn{1}{|c|}{ Kondisi Lingkungan } & \multicolumn{1}{c|}{ Vout smoke detector } \\
\hline Tidak Ada Asap & $0.706 \mathrm{mV}$ \\
\hline Asap Sedang & $3.081 \mathrm{~V}$ \\
\hline Asap Banyak & $4.89 \mathrm{~V}$ \\
\hline
\end{tabular}

\section{Hasil Pengujian}

Pada tahap analisis ini penulis akan melakukan analisa berdasarkan hasil pengujian yang telah dilakukan pada alat penanggulangan kebakaran.

Tabel 3. Hasil Pengujian Alat Penaggulangan Kebakaran

\begin{tabular}{|c|c|c|c|c|c|c|c|}
\hline Kondisi & $M Q 2$ & Kondisi & $\begin{array}{l}\text { Flame } \\
\text { Sensor }\end{array}$ & $\begin{array}{c}\text { Buzzer } \\
\text { Berbunyi }\end{array}$ & $\begin{array}{l}\text { ISD } 1820 \\
\text { Berbunyi }\end{array}$ & $\begin{array}{l}\text { Servo } \\
\text { Aktif }\end{array}$ & $\begin{array}{l}\text { Relay } \\
\text { Aktif }\end{array}$ \\
\hline Ada asap & Aktif & Ada api & Aktif & $\sqrt{ }$ & $\sqrt{ }$ & $\sqrt{ }$ & $\sqrt{ }$ \\
\hline $\begin{array}{c}\text { Tidak ada } \\
\text { asap }\end{array}$ & $\begin{array}{r}\text { Tidak } \\
\text { aktif }\end{array}$ & Ada api & Aktif & $\sqrt{ }$ & $\sqrt{ }$ & $\sqrt{ }$ & $\sqrt{ }$ \\
\hline Ada asap & Aktif & $\begin{array}{c}\text { Tidak ada } \\
\text { api }\end{array}$ & $\begin{array}{l}\text { Tidak } \\
\text { aktif }\end{array}$ & $\sqrt{ }$ & $\mathrm{x}$ & $\mathrm{x}$ & $\mathrm{x}$ \\
\hline $\begin{array}{c}\text { Tidak ada } \\
\text { asap }\end{array}$ & $\begin{array}{l}\text { Tidak } \\
\text { aktif }\end{array}$ & $\begin{array}{c}\text { Tidak ada } \\
\text { api }\end{array}$ & Aktif & $\mathrm{x}$ & $\mathrm{x}$ & $\mathrm{x}$ & $\mathrm{x}$ \\
\hline
\end{tabular}

Keterangan dari tabel diatas:

1. Saat terdapat asap dan terdeteksi oleh Sensor MQ2 Maka Buzzer akan aktif

2. Saat terjadi kebakaran/terdeteksi api oleh Flame Sensor maka Buzzer, ISD 1820, Servo dan relay akan aktif 


\section{PEMBAHASAN}

\section{Context Diagram}

Pada bagian ini dapat di jabarkan diagram dari System Control mengendalikan flame sensor dengan seri YL38 berbasis Arduino Uno. Context Diagram adalah perancangan terhadap sistem yang akan dirancang yang bersifat menyeluruh. Context Diagram digunakan untuk memudahkan proses penganalisaan terhadap sistem yang dirancang secara keseluruhan. Adapun Context Diagram yang dimaksud dapat dilihat pada gambar 2 dibawah ini:

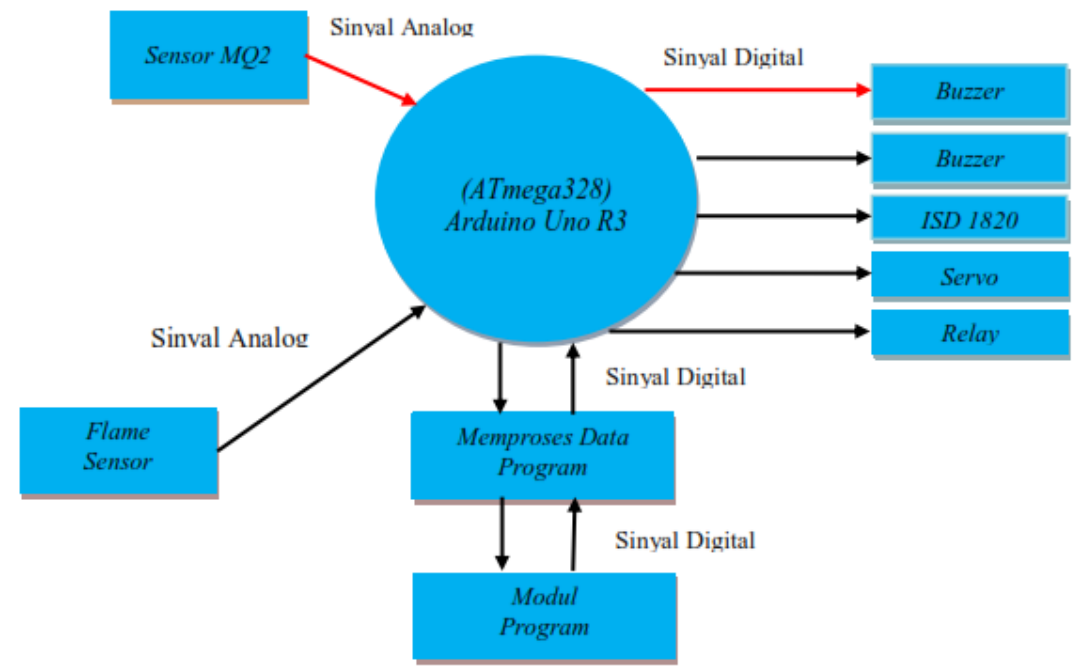

Gambar 5. Context Diagram Alat Penaggulangan Kebakaran

\section{Data Flow Diagram}

Data Flow Diagram sering digunakan untuk menggambarkan suatu sistem yang sudah ada atau sistem baru yang akan dikembangkan secara logika. Alat Penanggulangan Kebakaran ini diawali dari sensor MQ2, flame sensor dan mikrokontroler Arduino Uno, sensor MQ2 akan mendeteksi asap dan mengaktikan buzzer untuk berbunyi dan jika flame sensor mendeteksi api dari jarak tertentu. Setelah api terdeteksi, proses selanjutnya adalah mikrokontroler akan mengirim sinyal kepada buzzer untuk berbunyi, ISD 1820 untuk berbunyi, servo untuk membuka pintu darurat dan kepada relay untuk mengaktifkan pompa air. Berikut ini adalah Data Flow Diagram dari Alat Penanggulangan Kebakaran.

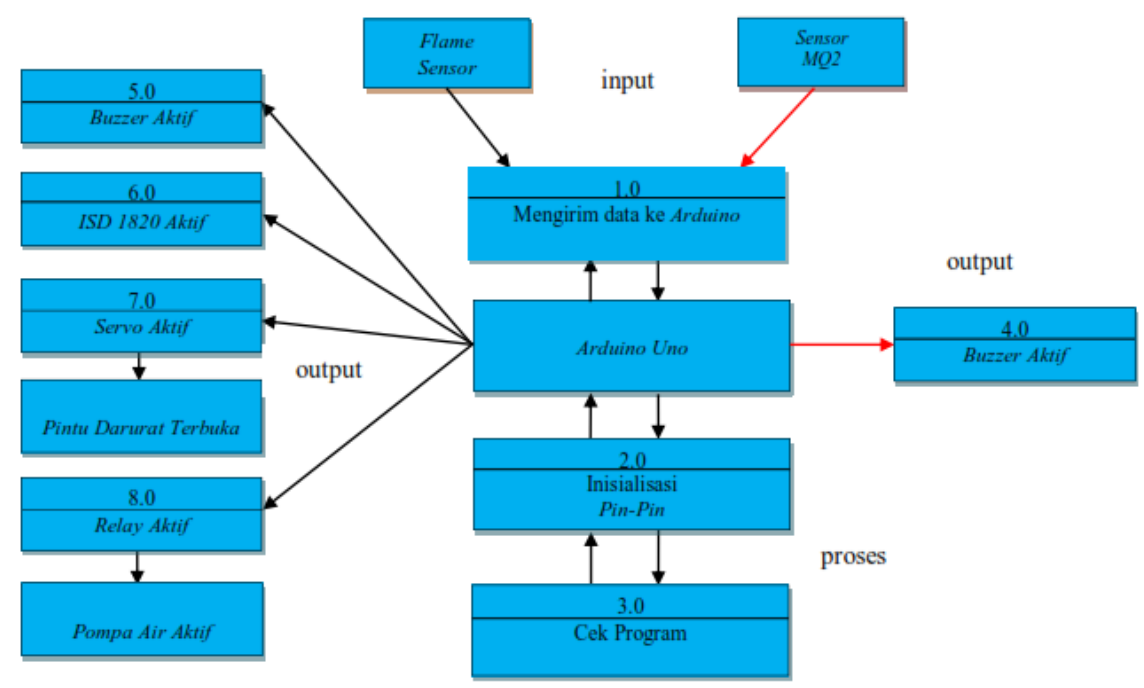

Gambar 6. Data Flow Diagram Alat Penanggulangan Kebakaran 
Flowchart

Dalam perancangan alat penanggulangan kebakaran yang didukung dengan bahasa pemrograman C, dan selanjutnya adalah perancangan logika yang merupakan dasar dari pemrograman penanggulangan kebakaran tersebut. Dalam penulisan skripsi ini digunakan flowchart.

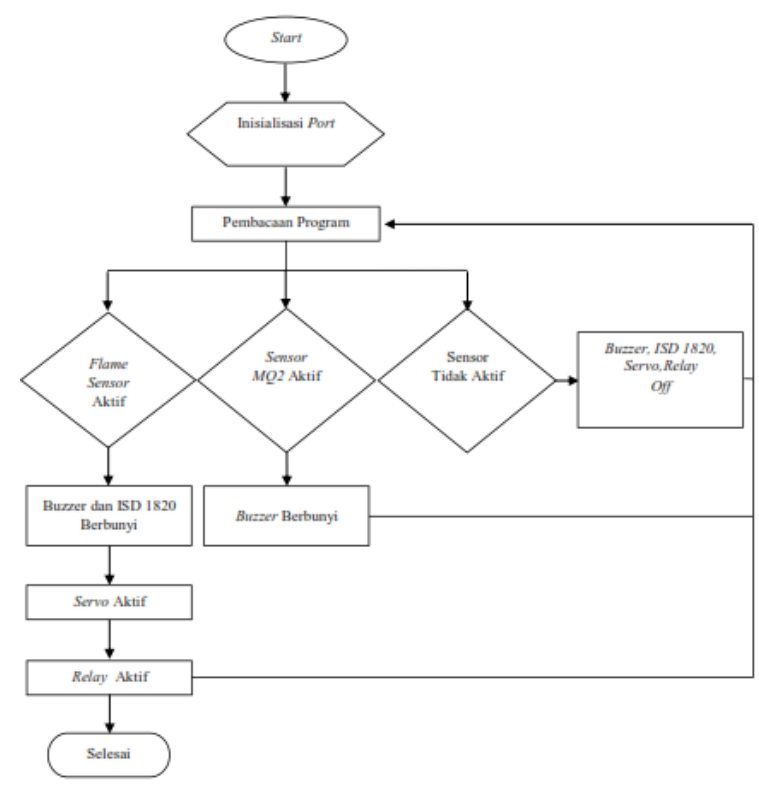

Gambar 7. Flowchart Alat Penanggulangan Kebakaran

\section{KESIMPULAN}

Berdasarkan analisis dan pembahasan yang telah di jelaskan, maka dapat di ambil hasil kesimpulan sebagai berikut: Dengan menerapkan system pemadam api ini dapat mengantisipasi terjadinya kebakaran yang sangat besar, karena alat yang diaplikasikan dengan mikrokontroller Arduino Uno serta menggunakan Sensor MQ2 untuk mendeteksi asap untuk memerintahkan peringatan suara dan Flame Sensor yang akan mendeteksi adanya api dan akan memerintahkan untuk memberikan peringatan suara, memadamkan api menggunakan sprayer air, serta membuka pintu darurat. Sistem pemadam api menggunakan Flame Sensor dan Sensor MQ2 yang diaplikasikan sebagai pendeteksi api dan asap yang ada di ruangan dan akan dikirim sebagai input ke mikrokontroller sehingga kita dapat menanggulangi dengan cepat jika terjadi kebakaran.

\section{REFERENSI}

Bahari, W. P., \& Sugiharto, A. (2019). Rancang Bangun Alat Pendeteksi Kebakaran Berbasis Internet of Things (IoT). Eprints.Uty.Ac.Id, 1, 1-9. http://eprints.uty.ac.id/3322/1/Naskah Publikasi_Widyatmoko Putra Bahari_5150711016.pdf

Iskandar Alam, T. H., Soekarta, R., \& Ramadhan, W. (2019). Rancang Bangun Prototype Alat Pendeteksi Kebakaran Menggunakan Arduino Uno Dilengkapi Pemadam Dan Notifikasi Sms Gateway. Insect (Informatics and Security): Jurnal Teknik Informatika, 5(1), 21. https://doi.org/10.33506/insect.v5i1.1280

Putra, M. F., Kridalaksana, A. H., \& Arifin, Z. (2017). Rancang Bangun Alat Pendeteksi Kebocoran Gas LPG Dengan Sensor Mq-6 Berbasis Mikrokontroler Melalui Smartphone Android Sebagai Media Informasi. Informatika Mulawarman : Jurnal Ilmiah Ilmu Komputer, 12(1), 1. https://doi.org/10.30872/jim.v12i1.215 